\title{
自由視点画像合成における見え方を考慮した レンズアレイ撮像系の設定
}

Use of View-Parameters in Free-Viewpoint Image Synthesis to Configure a Multi-View Acquisition System with Lens Array

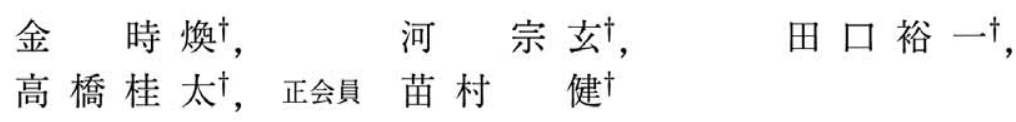

Sihwan Kim ${ }^{\dagger}$, Jonghyun $\mathrm{Ha}^{\dagger}$, Yuichi Taguchi ${ }^{\dagger}$, Keita Takahashi ${ }^{\dagger}$ and Takeshi Naemura ${ }^{\dagger}$

\begin{abstract}
We have been studying on a real-time Image-Based Rendering (IBR) system that uses a single camera with thousands of lenslets to capture multi-view images of dynamic 3D scenes and to synthesize arbitrary views of the scenes in real time. In our previous papers, we have formulated the upper limit of the spatial frequency captured with the optical system by analyzing the effects on the image sensor of blurring and sampling. In this paper, we defined view-parameters and formulated their relation with acquisition-parameters, which are used to decide the location setting of the devices. Our results showed that our theory is an effective way of designing acquistion-parameters for our real-time IBR system.
\end{abstract}

キーワード : Image-Based Rendering, レンズアレイ, LIFLET, 見え方のパラメータ, パラメータ設定

\section{1. ま え がき}

実世界の 3 次元視覚情報を扱う技術として, Image Based Rendering (IBR) $)^{1)}$ が注目を集めている. IBR では，ある 空間の多視点画像を利用し，その空間を自由な視点（仮想 視点）から見た画像（自由視点画像）を合成する. 多視点 画像の取得には, 一般的にカメラアレイ（多数のカメラを 格子状に並べた撮像系）が用いられるが2) 6), 大規模なカ メラアレイを構築するためには相当のコストがかかり，ま た, それらを密に並べることも物理的な制約上限界がある. そこで，筆者らのグループでは，カメラアレイの代わり に, レンズアレイ（数千個のマイクロレンズを密に並べた もの）を用いて多視点画像を取得し, 実時間で自由視点画像 の合成を行う IBR システム "LIFLET”(Light Field Live with Thousands of Lenslets) を提案した ${ }^{7)}$.これまで, LIFLET において，撮像系に奥行き制御レンズを導入する ことによる光学的歪みの除去 ${ }^{8)}$, 高画質の画像を得るため

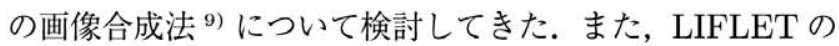
撮像系を使って撮像される多眼画像の空間周波数特性につ いても検討したが 10), 合成される自由視点画像における見

2006 年 7 月 4 日受付, 2006 年 8 月 23 日再受付, 2006 年 8 月 26 日採録 †東京大学 工学部

( ₹ 113-8656 文京区本郷 7-3-1, TEL 03-5841-6781)

$\dagger$ Faculty of Engineering The University of Tokyo

(7-3-1, Hongo, Bunkyo-ku, Tokyo 113-8656, Japan)

$1658(136)$

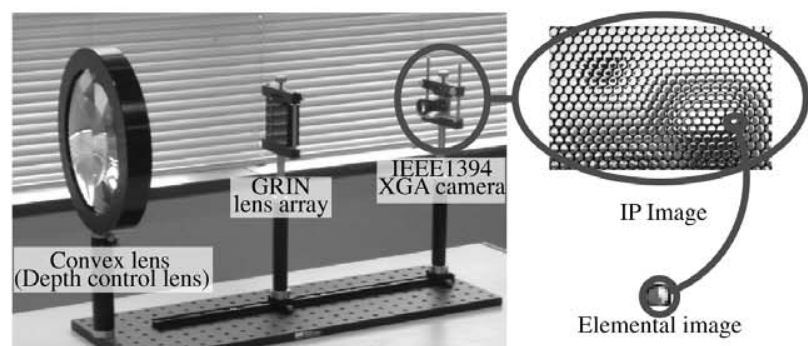

図 1 LIFLET の撮像系 Our capturing system "LIFLET".

え方については充分に議論されていなかったため, 撮像系 の設定は経験や試行錯䛊に頼ることが多かった.

本稿では，合成される自由視点画像の見え方に着目した レンズアレイ撮像系の設定手法 ${ }^{11) 12)} に$ にいて報告する．ま ず，見え方に関係する三つのパラメータ（視野角に収まる 被写体空間の幅, 視野の変化の大きさ, 被写体の鮮明さ) を定義し, それらのパラメータと撮像パラメータの関係を 明確にする. 結果として, 目標とする合成画像の見え方に 対して, どのように撮像パラメータを設定したらよいかと いう指針が示せるようになった.

\section{LIFLET:Light Field Live with Thou- sands of Lenslets}

LIFLET 撮像系の外観を図 1 に, LIFLET 撮像光学系を 


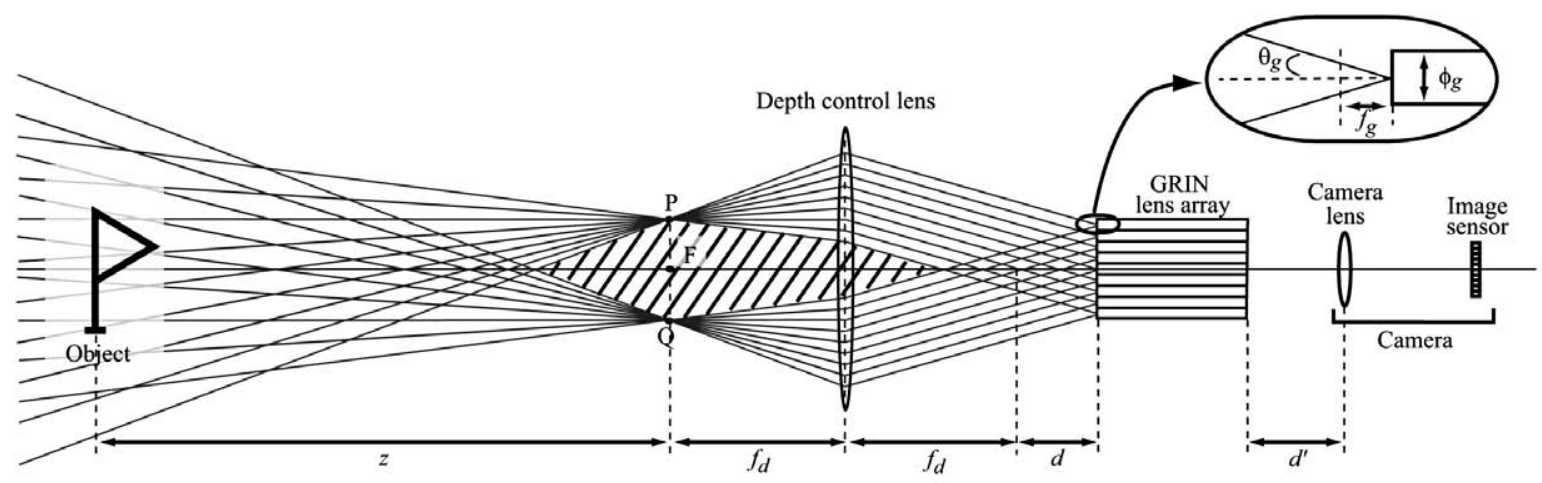

図 2 LIFLET 撮像光学系

Optical system of LIFLET.

表 1 光学系を構成する物理的パラメータ Physical parameters of optical devices.

\begin{tabular}{cl}
\hline \hline$\phi_{g}$ & diameter of GRIN lens \\
\hline$f_{g}$ & focal length of GRIN lens \\
\hline$\Theta_{g}$ & FOV of GRIN lens \\
\hline$f_{d}$ & focal length of depth control lens \\
\hline$N_{p}$ & number of pixels of IP Image \\
\hline$F_{c}$ & F-Number of camera lens \\
\hline$F_{c}^{\prime}$ & effective F-Number of camera lens \\
\hline$\delta_{c}$ & pixel pitch of image sensor \\
\hline \hline
\end{tabular}

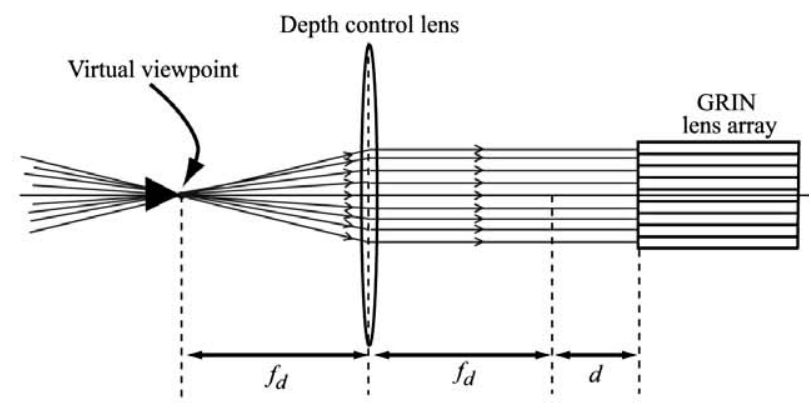

図 3 光線追跡による画像合成 Image synthesis by ray tracing.

図 2 に示す．撮像系は，奥行き制御レンズ（口径の大きな 凸レンズ), レンズアレイ, カメラからなる.レンズアレイ とは, 直径約 $1 \mathrm{~mm}$ のマイクロレンズを数千眼, 密に並べ たものであり, 各々のレンズが1台のカメラの役割をする. レンズアレイを構成するレンズとしては, 焦点が入射端面, 出射端面上に存在するような屈折率分布レンズ（GRINレ ンズ）を用いている ${ }^{13)}$.

被写体空間は奥行き制御レンズによって縮小され，レン ズアレイの入射端面付近に結像される。レンズアレイを構 成する個々のレンズはその位置から見た “縮小された被写体 空間” の像を出射端面付近に結像させ, レンズアレイの後方 端面を 1 台のカメラで撮影することで多視点画像 (Integral Photography(IP) 画像) が得られる. IP 画像中で, レン ズ 1 個に相当する円領域を “要素画像” (elemental image) と呼び, 小さなカメラ 1 台で撮影した画像に相当する.

自由視点画像は, 仮想視点を通る光線を追跡することで 合成される，例えば，仮想視点を図 3 の virtual viewpoint

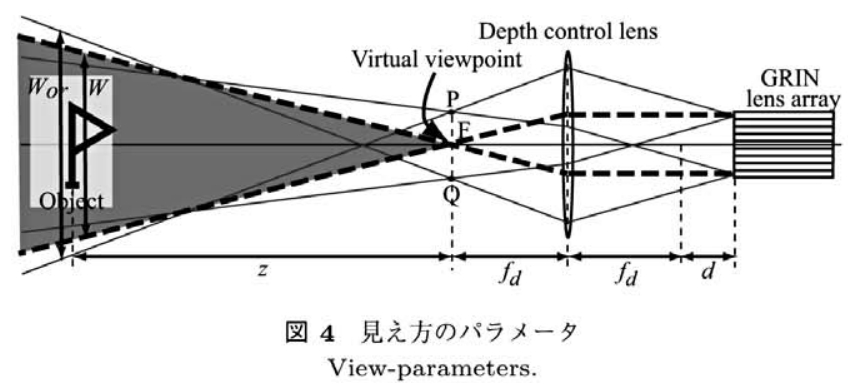

の位置に設定すると, その点を通る光線の経路をレンズア レイに向けてたどることができる. IP 画像上のこれらの光 線に相当する部分の色を使い, また, 適切な補間を用いる ことで仮想視点から見た画像が合成される．仮想視点の動 く範囲は，レンズアレイを構成するすべてのレンズから光 線を読出せる範囲と定義する（図 2 の斜線の部分）.

LIFLET システムにおいて, デバイスの物理的なパラ メー夕（表 1）を固定した場合, 入力データを取得する際 のパラメータ (“撮像パラメータ”) は, 図 2 における以下 の三つとなる.

・ $z$ : 奥行き制御レンズの前方焦点と被写体間の距離

- $d$ : 奥行き制御レンズの後方焦点とレンズアレイ入射端 面間の距離

- $n_{p}$ : 要素画像の直径方向の画素数 ( $d^{\prime}$ に依存)

これらのパラメータはLIFLET 撮像光学系におけるデバ イス間の距離であり，それぞれ奥行き制御レンズに対して， 被写体, レンズアレイ, カメラの位置に相当する.

\section{3. 見え方のパラメータの提案}

本章では, LIFLET システムにおいて “見え方のパラメー タ”を定義する. 目標は, 所望の見え方のパラメータに対 して適切な撮像パラメータを算出できるようにすることで ある、また, 多視点画像にならない領域を考慮した撮像パ ラメータと見え方のパラメータの制約条件について述べる.

\section{1 見え方のパラメータ}

合成された自由視点画像の見え方を特徴付ける，次のパ ラメータを見え方のパラメータと定義する（図 4 参照）. 


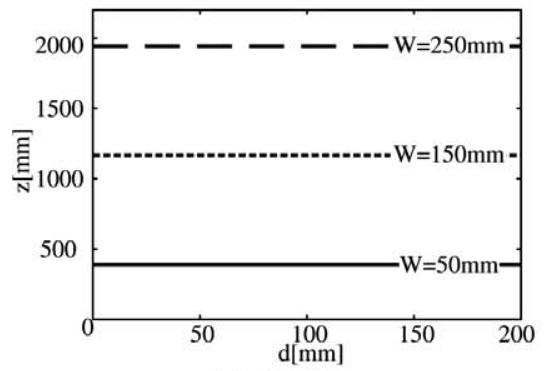

(a) $d-z$

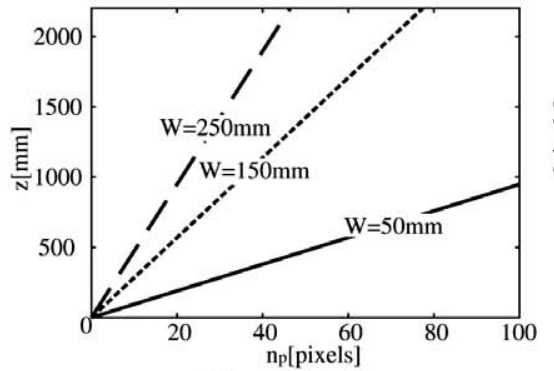

(b) $n_{p}-z$

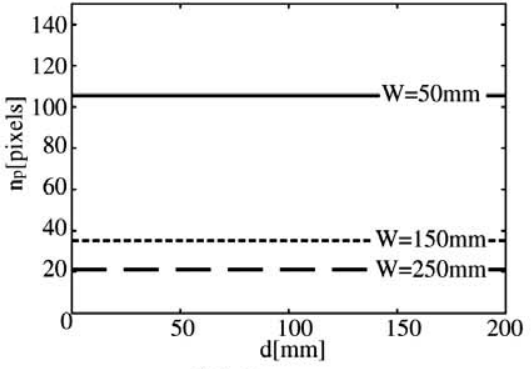

(c) $d-n_{p}$

図 5 合成画像の視野角に収まる被写体空間の幅 $W$ Width of object space at standard viewpoint : $W$.

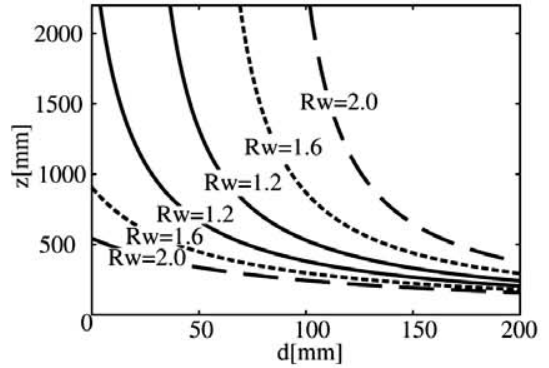

(a) $d-z$

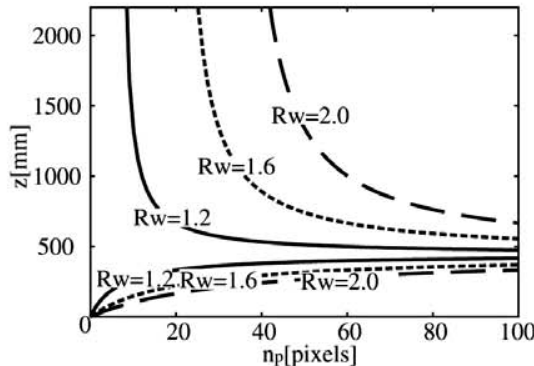

(b) $n_{p}-z$

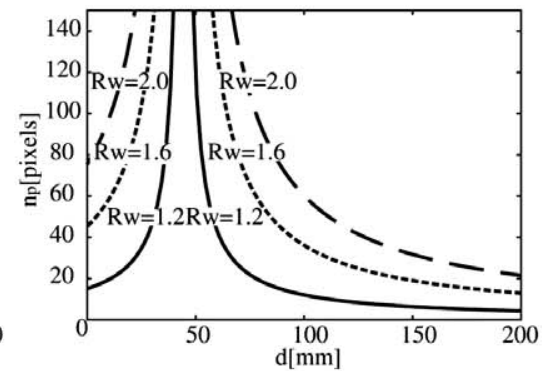

(c) $d-n_{p}$

図 6 視野の変化の大きさ $R_{w}$ Magnitude of change of view : $R_{w}$.

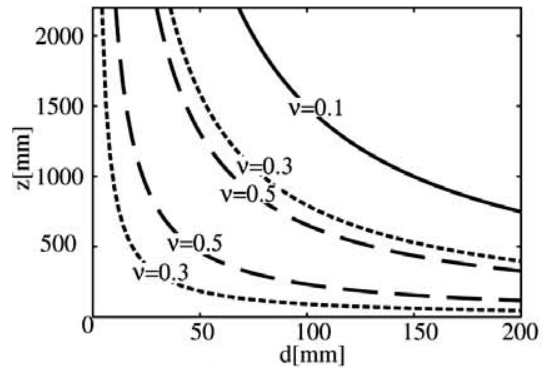

(a) $d-z$

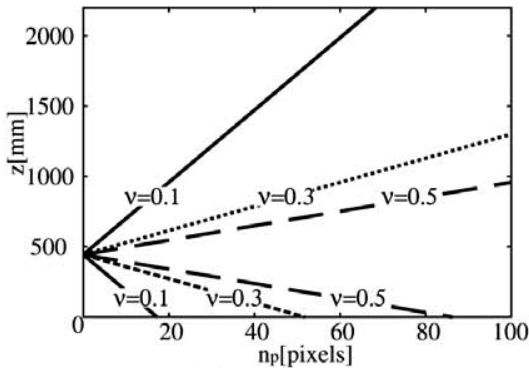

(b) $n_{p}-z$

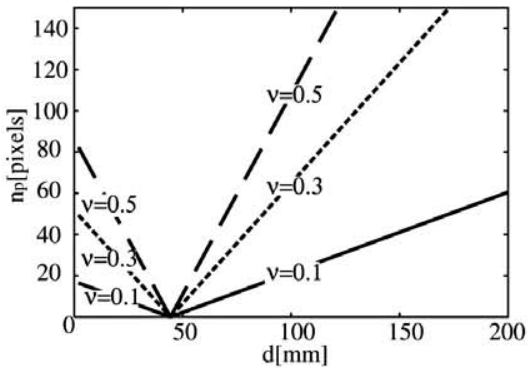

(c) $d-n_{p}$

図 7 カットオフ周波数 $\nu$ Cutoff frequency : $\nu$.

- $W$ : 合成画像の視野角に収まる被写体空間の幅

- $R_{w}$ : 視野の変化の大きさ

- $\nu$ : 被写体の鮮明さ（カットオフ周波数）

ここで, 仮想視点は光軸に対して左右の可動範囲が最も広 い $\mathrm{PQ}$ 上で動かすことにする．以下では，上記の見え方の パラメータを詳しく説明し, 撮像パラメータとの関係を示 す. 特に, 見え方のパラメー夕から, 撮像パラメー夕を逆 算できることが重要な目標である.

\section{（1）合成画像の視野角に収まる被写体空間の幅：W}

仮想視点を $\mathrm{PQ}$ の中心（点 F）において画像を合成する 場合を考え， $z$ においてその視野角に収まる被写体空間の 幅を $W$ と定義する（図 4). 点 $\mathrm{F}$ は奥行き制御レンズの 焦点と一致するため, 点 $\mathrm{F}$ を通過する各光線は奥行き制御 レンズを通過した後, 光軸に平行に直進する. したがって, レンズアレイの両端に位置するレンズから，光軸に平行な 光線をたどることにより (点線),$W$ と撮像パラメータの 関係が以下のように求められる。

$$
W\left(z, n_{p}\right)=\frac{N_{p}}{n_{p}} \phi_{g} \frac{z}{f_{d}}
$$

ここで, $N_{p} / n_{p}$ は合成に用いる要素画像の数であり, $W$ は $N_{p} / n_{p}$ と $z$ に比例する.

（2）視野の変化の大きさ： $R_{w}$

仮想視点を $\mathrm{PQ}$ 上で動かした時に，各位置において被写 体空間をそれぞれ違う角度から見た画像が合成される。こ れらの視野角に収まる幅の全域（論理和）を $W_{\text {or }}$ と定義す る (図 4$) . W_{o r} / W$ は, 仮想視点を $\mathrm{PQ}$ 上で移動したとき に, 合成画像の視野に含まれる範囲が変化する度合いを表 しており，これを視野の変化の大きさ $R_{w}$ として定義する. （詳細については付録 $\mathrm{A}$ を参照されたい）

$$
R_{w}\left(z, d, n_{p}\right)=1+\frac{2 n_{p} \tan \Theta_{g}}{N_{p} \phi_{g}}\left|d-\frac{f_{d}^{2}}{z}\right|
$$

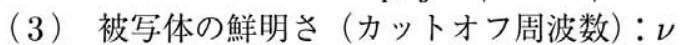

LIFLET システムでは，レンズ系における焦点ほけと撮 像素子におけるサンプリングの影響によって劣化した多視 点画像が取得される，さらに，自由視点合成画像では，合 
成アルゴリズムに依存したぼけが加わる，ここでは，合成 アルゴリズムが理想的な場合を考え, 合成の段階でのぼけ を無視する．また，経験上，レンズ系における焦点ほけの 影響はほとんどないため, 撮像素子におけるサンプリング の影響によるぼけを, 合成される画像のほける程度を表す 指標とする. 小島ら ${ }^{10)}$ の理論に従い, カットオフ周波数 $\nu$ は次のようになる.

$$
\nu\left(z, d, n_{p}\right)=\frac{n_{p}\left|f_{g}\right|}{2 \phi_{g}} \frac{f_{d}}{|d|} \frac{1}{\left|z-f_{d}^{2} / d\right|}
$$

撮像パラメータを軸とした $d-z$ 平面 $\left(n_{p}=41\right.$ pixel, 固定), $n_{p}-z$ 平面 $\left(d=100 m m\right.$, 固定),$d-n_{p}$ 平面 $(z=1000 \mathrm{~mm}$, 固定 $)$ に执いて, 各見え方のパラメー夕 $\left(W, R_{w}, \nu\right)$ を一定として描いた等高線を図 $\mathbf{5}$, 図 $\mathbf{6}$, 図 7 に示す. 特に $R_{w}$ と $\nu$ は撮像パラメー夕に対して非線形 に変化するため, 撮像系を設定する際に試行錯誤によって 目標とする值に近付くことは必ずしも容易ではない.

しかし, 見え方のパラメータ $\left(W, R_{w}, \nu\right)$ を一意に決 めると, 撮像パラメー夕 $\left(z, d, n_{p}\right)$ を逆に求めることが できる. (1)-(3) 式を変形することにより求められた撮像 パラメータを (4)-(6) 式に表す. 同じ見え方のパラメータ の值に対して,$z$ と $n_{p}$ は一意に決まるが, $d$ は二つの值を 持つことがわかる.

$$
\begin{aligned}
& z\left(W, R_{w}, \nu\right)=\frac{f_{d} \nu W^{2}}{N_{p}\left|f_{g}\right| \tan \Theta_{g}}\left(R_{w}-1\right) \\
& d\left(W, R_{w}, \nu\right)=\frac{N_{p}\left|f_{g}\right|}{\nu W}\left(\frac{f_{d} \tan \Theta_{g}}{W\left(R_{w}-1\right)} \pm \frac{1}{2}\right) \\
& n_{p}\left(W, R_{w}, \nu\right)=\frac{\phi_{g} \nu W}{\left|f_{g}\right| \tan \Theta_{g}}\left(R_{w}-1\right)
\end{aligned}
$$

\section{2 多視点画像にならない領域の考慮}

LIFLET システムには，奥行き制御レンズを用いること により, 図 8 のように多視点画像として取得できない領域 (“NGゾーン”) が存在する ${ }^{9)}$. 図 8 において, 灰色付きの 部分は各レンズの視野を表すが, NGゾーンの中では, 同 時に二つ以上のレンズの視野に入らない領域ができるため, その部分は多視点画像にならない. NG ゾーンにおける撮 像パラメータは (7) 式で表される.

$$
\frac{f_{d}^{2}}{d+2\left|f_{g}\right|} \leqq z \leqq \frac{f_{d}^{2}}{d-2\left|f_{g}\right|}
$$

この NGゾーンを考虑せずに見え方のパラメータを設定 すると，(4)-(6) 式によって計算される撮像パラメータが (7) 式の範囲に入り, 自由視点画像の合成ができなくなる場 合がある，そのため，NGゾーンに含まれないための見え 方のパラメータの条件を調べる必要がある.

(7) 式に (4)-(6) 式を代入することで NGゾーンにおけ る見え方のパラメータを求めると (8) 式のようになる.

$$
W \nu>\frac{N_{p}}{4}
$$

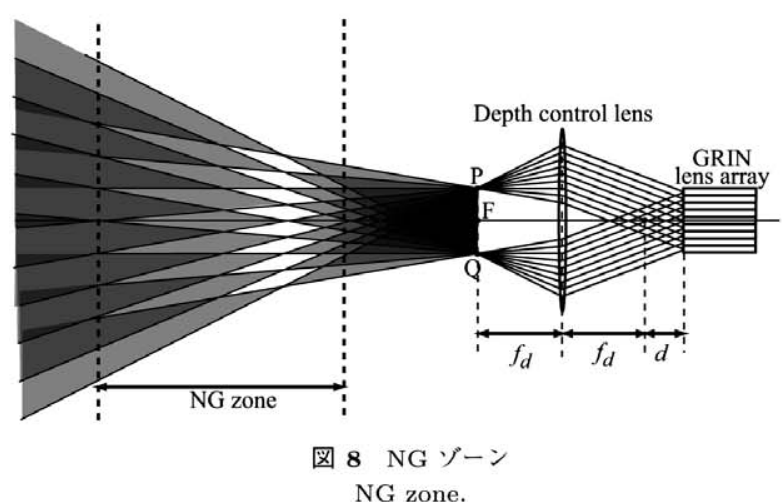

表 2 実験に用いたデパイスの物理的パラメー夕の值 Physical parameters in this experiment.

\begin{tabular}{cll}
\hline \hline$\phi_{g}$ & diameter of GRIN lens & $1.085 \mathrm{~mm}$ \\
\hline$f_{g}$ & focal length of GRIN lens & $-2.65 \mathrm{~mm}$ \\
\hline$f_{d}$ & focal length of depth control lens & $210.6 \mathrm{~mm}$ \\
\hline$N_{p}$ & number of pixels of IP Image & 2800 pixel \\
\hline$\Theta_{g}$ & FOV of GRIN lens & $5.425^{\circ}$ \\
\hline \hline
\end{tabular}

ここで, $N_{p}$ (IP 画像の 1 辺の画素数) はカメラの画素 数の制約を受ける。この式は, NGゾーンに含まれないた めには, $W$ と $\nu$ 積が $N_{p} / 4$ より小さくなければならない ことを意味する. また, $N_{p}$ が固定された場合, $W$ と $\nu$ が トレードオフ関係であることがわかる.

\section{4. 実 験}

本章では, 3 章の議論を確認するための実験を行う．まず, 見え方のパラメー夕を与え，それに対する撮像パラメー夕を 算出する. 次に, 算出された撮像パラメータを基に LIFLET 撮像系を設定する. 最後に, IP 画像を取得し，それから自 由視点画像を合成する.

撮像系のデバイスの物理的パラメータを表 2 に示す。 た だし $\Theta_{g}$ は, $\mathrm{PQ}$ 上で実際に視点位置を動かして視覚的に許 容できる画像が合成可能であった範囲から逆算した值をもっ て実効值 $\left(5.425^{\circ}\right)$ とした. レンズアレイを撮影するカメラ として, 高画質のディジタル一眼レフカメラ (Canon EOS D-60，3072×2048pixel）を用いた．被写体は，花の模型 (幅約 $40 \mathrm{~mm}$ ), 電車型の玩具 (幅約 $120 \mathrm{~mm}$ ), “LIFLET" と書いた板（幅約 $300 \mathrm{~mm}$ ) である. 自由視点画像の合成 には河ら 9)の手法を用いた。

まず, 表 3 のように, 3 通りの見え方のパラメー夕を設 定した．Aでは，被写体（花の模型）が合成画面に入るよ うに $W$ を設定し，(8) 式を考慮して $\nu$ の值を決めた. B は $\mathrm{A}$ に対して $R_{w}$ の值のみを大きくした. $\mathrm{C}$ は $\mathrm{A}$ に対して $R_{w}$ を固定し, $W$ と $\nu$ を変化させた. 見え方のパラメー夕 に基づいて，(4)-(6) 式により計算された撮像パラメー夕 を表 4 に示す．ここでは，(5) 式の符号が負の場合を選択 した.

次に, 表 4 の計算された撮像パラメー夕を基に, 被写体, レンズアレイ, カメラを配置した. 被写体は, 算出された $z$ の位置に電車型の玩具の前面を合わせ, その直前に花の模 


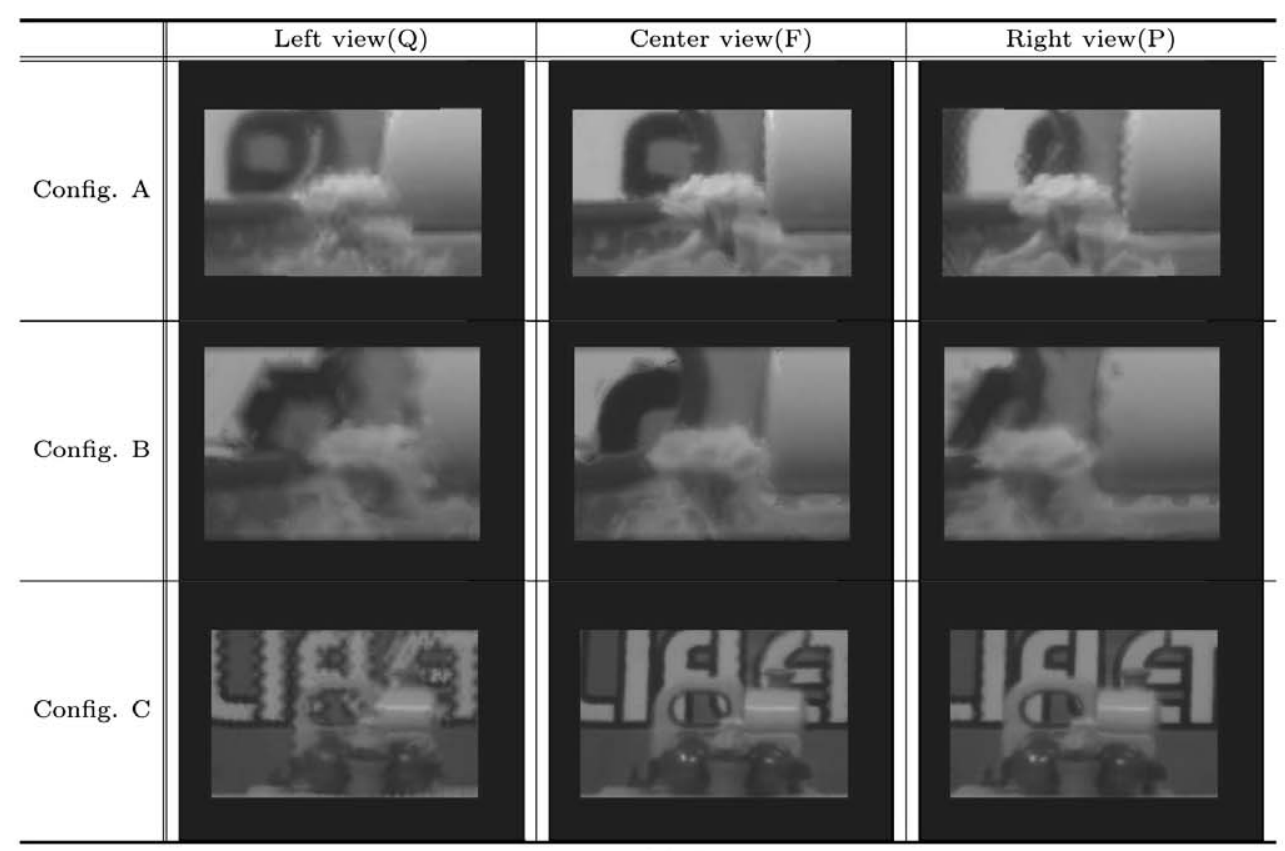

図 9 合成結果

Synthetic results.

表 3 見え方のパラメータの設定

Configuration of view-parameters.

\begin{tabular}{c||c|c|c}
\hline \hline Config. & $W[\mathrm{~mm}]$ & $R_{w}$ & $\nu[$ cycle $/ \mathrm{mm}]$ \\
\hline $\mathrm{A}$ & 50 & 1.1 & 4.0 \\
\hline $\mathrm{B}$ & 50 & 1.2 & 4.0 \\
\hline $\mathrm{C}$ & 200 & 1.1 & 1.0 \\
\hline
\end{tabular}

表 4 撮像パラメータの導出 Calculated acquisition-parameters.

\begin{tabular}{c||c|c|c}
\hline \hline Config. & $z[\mathrm{~mm}]$ & $d[\mathrm{~mm}]$ & $n_{p}[$ pixel $]$ \\
\hline A & 298.9 & 129.9 & 86.22 \\
\hline B & 597.7 & 55.65 & 172.5 \\
\hline C & 1195 & 18.55 & 86.22 \\
\hline
\end{tabular}

型を，背景として遠方に“LIFLET”と書いた板を置いた. 設定した撮像系を用いて IP 画像を取得し，自由視点画像 を合成した結果を図 9 に示す。ここで, Left view, Center view, Right view とは, 仮想視点を図 2 の左視点（点 $Q$ ）, 基準視点（点 $\mathrm{F}$ )，右視点（点 $\mathrm{P}$ ）において合成した画像 である。まず，Aの Center View において，合成画像に 収まっている花の模型の大きさから，おおよそ目標とした $W(=50 \mathrm{~mm})$ が得られていることがわかる. 次に A と B を 比較すると，視野に収まる面積はほぼ同じであるが，視点 の移動にともなって, B の方が, 花の位置が大きく変化し ていることがわかる.これは，Bにおいて， $R_{w}$ がより大き いことに対応する，そして， A, C を比較すると， C はよ り大きい被写体空間を視野に収めているが（Wが大きい）, $\mathrm{C}$ の一部を拡大したものに相当する $\mathrm{A}$ の方が細部をより鮮

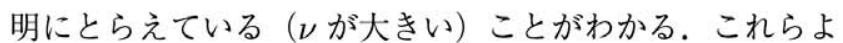
り, $R_{w}$ と $\nu$ についても, 定性的な大小関係が設計と一致 することを確認できた.

これらの結果から，見え方のパラメータを決めることに より，それに応じて撮像パラメータを設定することが可能 であることがわかる。

\section{5. むす び}

本稿では，レンズアレイ撮像系を用いた自由視点画像合 成システム（LIFLET）において，その見え方を考慮した
撮像パラメータの設定について検討した．まず, LIFLET システムにおいて，合成される画像の見え方を特徴付ける “見え方のパラメータ”を定義し, 入力データの取得条件を 特徽付ける “撮像パラメータ”との関係式を求めた. 次に, この関係式に基づき，多視点画像にならない領域も考慮に 入れた撮像パラメータの設定について検討を行った。また， 実際の撮像パラメータの設定, 撮像, 自由視点画像の合成 を通じて，上記の検討の有効性を確認した．今後の課題と しては, LIFLET システムのデバイスの物理的パラメータ を変更した場合のシステム機能の向上に関する検討が考え られる。

最後に, 有益なご助言を頂いた東京大学の原島博教授に 深く感謝致します. 本研究の一部は, 総務省戦略的情報通 信研究開発推進制度（SCOPE）の支援を受けて行われま した。

\section{〔文献〕}

1) H.-Y. Shum, S.-B. Kang, and S.-C. Chan: "Survey of ImageBased Representations and Compression Techniques," IEEE Trans. Circuits Syst. Video Technol., 13, 11, pp. 1020-1037 (Nor. 2003)

2) T. Naemura, J. Tago, and H. Harashima: "Real-Time Video Based Modeling and Rendering of 3D Scenes," IEEE Comput. Graphics \& Appl., 22, 2, pp. 66-73 (Mar. 2002)

3) J.C. Yang, M. Everett, C. Buehler, and L. McMillan: "A RealTime Distributed Light Field Camera," Proc. 13th Eurographics Workshop on Rendering, pp. 77-85 (June 2002)

4) B. Wilburn, M. Smulski, K. Lee, and M.A. Horowitz: "The Light Field Video Camera," Proc. Media Processors 2002, SPIE Elec- 
tronic Imaging 2002, pp. 29-36 (Jan. 2002)

5) C. Zhang and T. Chen: "A Self-Reconfigurable Camera Array," Proc. 15th Eurographics Symposium on Rendering, pp. 243-254 (June 2004)

6) M. Tanimoto: "FTV (Free Viewpoint Television) Creating RayBased Image Engineering," Proc. IEEE ICIP 2005, 2, pp. 25-28 (Oct. 2005)

7) T. Yamamoto, M. Kojima, and T. Naemura: "LIFLET: Light Field Live with Thousands of Lenslets," ACM SIGGRAPH 2004 Emerging Technologies, etech0130 (Aug. 2004)

8）山本智幸, 苗村健：“屈折率分布レンズ方式 IBR システムにおける奥行 き圧縮効果の除去”, 信学技報, IE2003-105 (Nov. 2003)

9）河宗玄, 小島將, 高橋桂太, 苗村健：“レンズアレイを用いた実時間全焦点 自由視点画像合成システム”, 映情学誌, 59, 10, pp. 1483-1487 (Sep. 2005)

10）小島將，苗村健：“レンズアレイを用いた自由視点画像合成システムに おける撮像光学系の空間周波数特性”, 映情学誌, 59, 4, pp. 569-580 (Mar. 2005)

11）金時煥, 河宗立, 田口裕一, 高橋桂太, 苗村健: “自由視点画像合成におけ る見え方の変化を考虑したレンズアレイ撮像系の設計に関する基礎検 討”, 信学総大, D-11-63 (Mar. 2006)

12）金時煥, 河宗玄, 田口裕一, 高橋桂太, 苗村健: “自由視点画像合成におけ る見え方を考慮したレンズアレイ撮像系の設計”, 3 次元画像コンファレ ンス, 5-1, pp. 73-76 (Jul. 2006)

13) J. Arai, F. Okano, H. Hoshino, and I. Yuyama: "Gradient-Index Lens-Array Method Based on Real-Time Integral Photography for Three-Dimensional Images," Appl. Opt., 37, 11, pp.20342045 (Apr. 1998)

〈付録〉

A. 視野の変化 $R_{w}$ の導出過程

A. $1 z<f_{d}^{2} / d$ (図 1) の場合

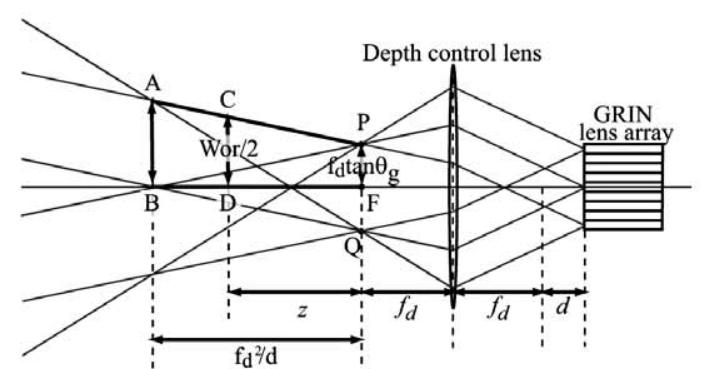

付·図 $1 R_{w}\left(z<f_{d}^{2} / d\right.$ の場合 $)$

$R_{w}$ (case of $\left.z<f_{d}^{2} / d\right)$.

$W_{o r}$ は四角形 $\mathrm{PABF}$ の中の $\mathrm{CD}$ の長さ $(\overline{C D}) \times 2$ に 相当する. $\mathrm{PF}$ の長さ $\left(\overline{P F}=f_{d} \tan \Theta_{g}\right), \mathrm{AB}$ の長さ $\left(\overline{A B}=\frac{N_{p}}{2 n_{p}} \phi_{g} \frac{f_{d}}{d}\right)$ と比例関係から $W_{o r}$ を求めると，(付 •1) 式となる.

$$
W_{\text {or }}=z\left(\frac{N_{p} \phi_{g}}{n_{p} f_{d}}-\frac{2 d}{f_{d}} \tan \Theta_{g}\right)+2 f_{d} \tan \Theta_{g} \text { (付·1) }
$$

(付·1) 式と (1) 式から $R_{w}$ を求めると, 次のようになる.

$$
R_{w}\left(z, d, n_{p}\right)=1-\frac{2 n_{p} \tan \Theta_{g}}{N_{p} \phi_{g}}\left(d-\frac{f_{d}^{2}}{z}\right)
$$

A.2 $z>f_{d}^{2} / d$ (図 2) の場合

$W_{o r}$ は $\mathrm{CD}$ の長さ $(\overline{C D}) \times 2$ に相当する. 三角形 KIJ か ら $x(\overline{J K})$ は (付·3) 式となる. また, レンズの結像公式から (付·4) 式が, 三角形 EAB と三角形 ECD の相似関係から (付·5) 式が成り立つ.これらの式から $W_{o r}$ が求まり，(付 ·6) 式となる.

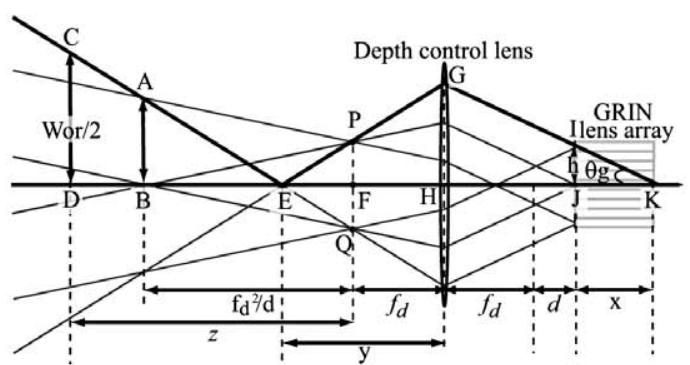

付·図 $2 R_{w}\left(z>f_{d}^{2} / d\right.$ の場合 $)$ $R_{w}\left(\right.$ case of $\left.z>f_{d}^{2} / d\right)$.

$$
\begin{aligned}
& x=\frac{N_{p} \phi_{g}}{2 n_{p} \tan \Theta_{g}} \\
& \frac{1}{x+f_{d}+d}+\frac{1}{y}=\frac{1}{f_{d}}
\end{aligned}
$$

$\frac{f_{d}^{2}}{d}-y+f_{d}: \frac{\overline{A B}}{2}=z-y+f_{d}: \frac{W_{o r}}{2}$

$$
W_{o r}=\frac{N_{p} \phi_{g}}{n_{p} f_{d}}\left\{\frac{z(x+d)-f_{d}^{2}}{x}\right\}
$$

(付·6) 式と (1) 式から $R_{w}$ を求めると, 次のようになる.

$$
R_{w}\left(z, d, n_{p}\right)=1+\frac{2 n_{p} \tan \Theta_{g}}{N_{p} \phi_{g}}\left(d-\frac{f_{d}^{2}}{z}\right)
$$

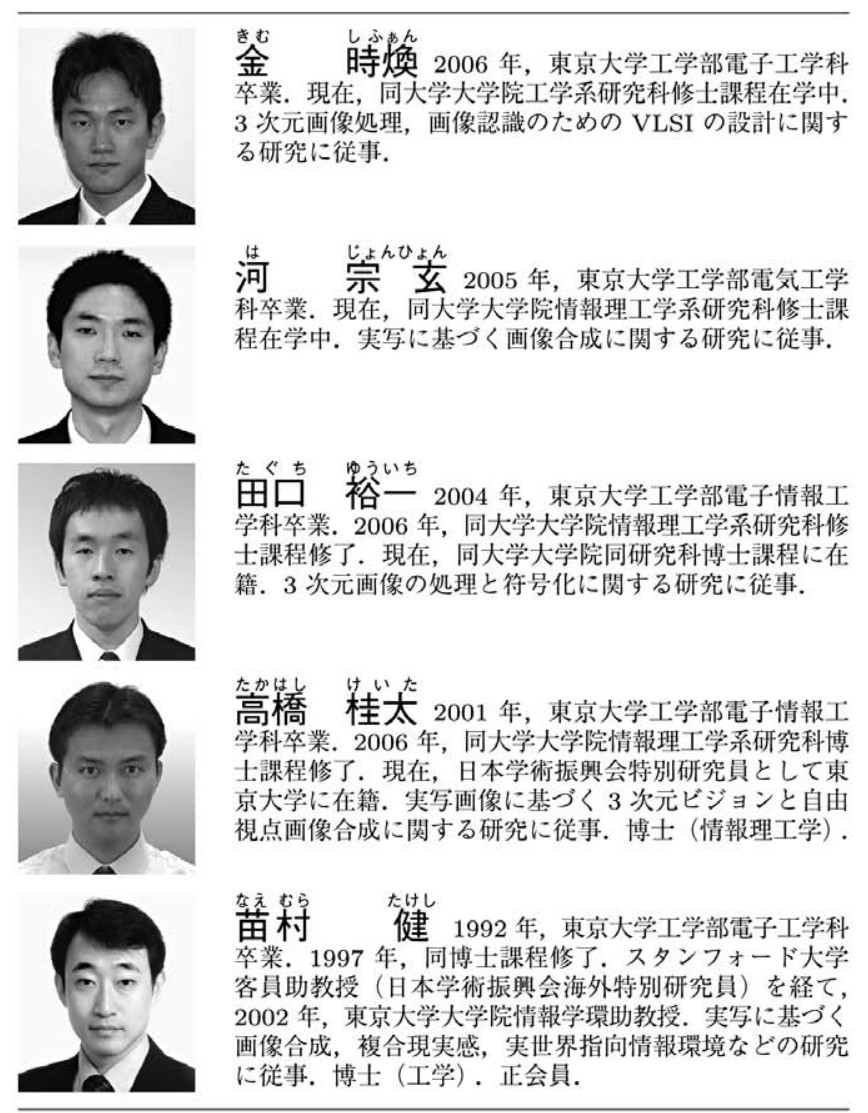

